\title{
Modification of the PJBL Learning Model to Become HBL as an Alternative to Learning During the Covid-19 Pandemic in Science Subjects for Grade 3 Elementary School at Indonesian Nature School Cibinong
}

\author{
Rima Aulia*, Herawati, Karwati, Asep Tajussobirin, Ramdhan Sukrilah \\ Magister Teknologi Pendidikan Sekolah Pasca Sarja Universitas Ibn Khaldun Bogor \\ *Corresponding author email: rimaauliaalkhonsa@gmail.com
}

\begin{abstract}
This research is development research to develop a learning model during the Covid 19 pandemic, to analyze the feasibility and effectiveness of the model. The problem in this study is formulated as follows: how to apply HBL as a form of adaptation to PjBL in the era of the Covid-19 pandemic at the Indonesian Nature School in Cibinong? How is the feasibility of implementing the HBL model as an alternative to learning science in the Covid-19 pandemic era? , and how is the science learning achievement achieved by students after applying HBL to the PjBL model? The method used in this study is the ADDIE (Analysis, Design, Development, Implementation, and Evaluation) development model. This research was conducted at the Indonesian Nature School Cibinong. The sample in this study using the purposive sampling technique. Data analysis used the percentage formula, Product Moment for validity test, Alpha Cronbach for reliability test, Monte Carlo for normality test, and t-test to see the effectiveness of the HBL model. The data in this study were collected by filling out questionnaires, documenting activities, field observations, and doing assignments by students. The results of the research on the feasibility of the HBL model by instructional design experts were $84 \%$ and material experts were $94 \%$ which means very feasible. The results of the feasibility test from the users consisted of teachers by $67 \%$ which means feasible, parents of students by $79.1 \%$ which means very feasible, and students by $90.3 \%$ which means very feasible. Based on due diligence by experts/experts and due diligence by users, the HBL model is declared very feasible to be applied in learning during the pandemic and HBL can improve science learning achievement during the Covid-19 pandemic.
\end{abstract}

Keywords: HBL Model, distance learning, ADDIE, learning achievement

\section{INTRODUCTION}

Education is a deliberate effort to achieve a goal. Education to develop a very important part of developing the quality of human resources. One indicator of this increase is through learning achievement. Learning achievement in the world of education is a part that cannot be entered because from this everyone can see from each student. Achievement is a result that is achieved from the teaching and learning process where these activities can be found anywhere, one of which is an educational institution called a school. New learning achievements can be achieved after students experience the learning process. Learning achievement is expressed in the form of a value or value that is known after the measurement is done using tests.

Learning is a nature that is given by the Creator to a creature called a human. Learning has an important position in life because through learning three basic human relationships will develop, communication skills, social awareness, and environmental conditions. Through learning someone is expected to be able to change their behavior for the better. Cronbach in Sumadi Suryabrata (2010: 231) the best learning is by experiencing and experiencing it, students use their five senses. The five senses are not limited only to the sense of sight, but also to the other senses. Cronbach's opinion above regarding learning stops that learning will be effective if in the process all human senses are used. Based on some of the opinions expressed, if considered editorial, of course, they differ from one another, but essentially all of these opinions refer to the same aims, objectives, and concepts and have the same elements, namely: (1) Individual who learns, (2) There is learning as a process, (3) Learning outcomes as a result of changes in behavior, (5) The learning process that occurs in interaction with the environment. The above explanation, it can show that learning is a pleasant change by individuals or 
students as a result of interaction with their environment, the learning outcomes obtained are increased knowledge, skills, values, and attitudes, as well as new habits.

In addition to the term learning, in the world of education, learning is also familiar. According to Wahab Zufri $(2013,40)$, the term learning is more influenced by developments for learning needs, in which students are positioned as learning subjects who play a major role. Students are facilitated to be able to move individually or in groups in the learning process. In good learning, there must be an interaction between educators and students where this interaction results in learning achievement.

According to Sardiman AM (2001: 46), Learning achievement is a real ability that is the result of the interaction between various factors that influence both from within and from outside the individual in learning. Based on these limitations, learning achievement can be interpreted as tangible skills that can be measured in the form of knowledge, attitudes, and skills as an active interaction between learning subjects and learning objects during the teaching and learning process to achieve learning outcomes. The important thing that influences the learning process to produce learning achievement, one of which is the selection of a learning model.

According to Syaiful Sagala (2011: 176) expressed the opinion that "The learning model is a conceptual framework that describes a systematic procedure for organizing learning experiences to achieve certain learning objectives, and serves as a guide for learning designers and teachers in planning teaching and learning activities". The learning model used by Sekolah Alam Indonesia is the PjBL Model (Project Based Learning) or project-based learning. CORD in Sutirman (2013: 43) explains that projectbased learning is an innovative learning model that focuses on contextual learning through complex activities. The PjBL model can link higher-order thinking skills (Higher Order Thinking Skills / HOTS) to students. HOTS can be achieved when students actively understand and integrate knowledge with their experiences (Anderson \& Krathwohl, 2015).

Based on this description, the Indonesian Nature School still maintains the PjBL Model to apply the curriculum in the learning process. The condition of the Covid-19 pandemic which requires learning to be carried out at home makes PjBL need to be modified so that it is relevant to use. The implementation of distance learning makes $\mathrm{PjBL}$ meet many challenges that are felt by teachers,

The analysis stage (Analyze) includes needs analysis, student characteristics, prerequisite analysis and initial ability, and learning environment parents, and students so that it affects student learning achievement. Based on the results of the distance learning evaluation (PJJ) conducted from March to June 2020, the science learning achievement achieved by students has decreased to below the KKM. There is no choice but for schools to develop the PjBL model so that it can be run even if the school is conducted at home. Home Based Learning (HBL) is one of the PjBL models developed by Sekolah Alam Indonesia as a form of learning adaptation in the pandemic era so that students stay in school even at home.

The formulation of the problem in this study is how to implement $\mathrm{HBL}$ as a result of $\mathrm{PjBL}$ modification with the ADDIE development model, how is the feasibility of implementing the HBL model as an alternative to learning in the pandemic era, and how the science learning achievement achieved by students after implementing HBL. The objectives to be achieved are based on the formulation of the problem, namely: developing the $\mathrm{PjBL}$ model into HBL as an alternative form of learning model during the Covid-19 pandemic, analyzing the feasibility of the $\mathrm{PjBL}$ model to become HBL as an alternative form of class 3 science learning model at SD SAI Cibinong during the Covid pandemic. -19 , and analyzing the level of effectiveness of HBL in improving science learning achievement for grade 3 at SD SAI Cibinong.

\section{METHOD}

This type of research is Research and Development (R\&D). The product developed in this study was the development of the PjBL learning model to become HBL (Home Based Learning) as an alternative to learning during the Covid-19 pandemic in natural science subjects for grade $3 \mathrm{SD}$ at Sekolah Alam Indonesia Cibinong. The development model carried out is the ADDIE (Analysis, Design, Development, Implementation, and Evaluation).

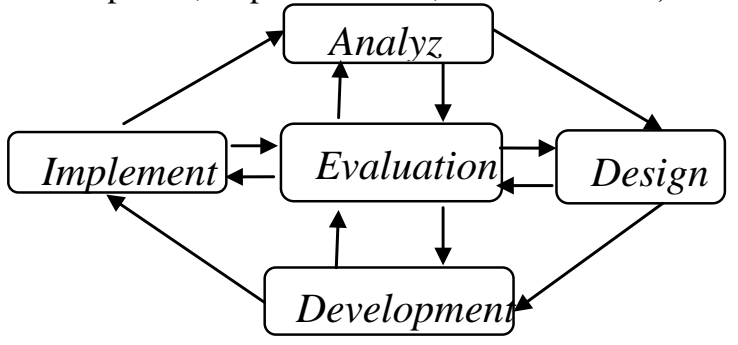

Figure 1. ADDIE Model

analysis. The design stage includes the design of the subject matter design, celebration, the learning process (starting from brainstorming - evaluation 
and reflection), and instruments for assessing $\mathrm{HBL}$ models. The next stage is development, including developing $\mathrm{PjBL}$ to become $\mathrm{HBL}$, choosing $\mathrm{HBL}$ implementation strategies, expert/expert validation tests. The next stage is the implementation stage, namely: the implementation of the HBL model into 7 elements and the HBL feasibility test by practitioners (teachers, parents, and students). The last stage is an evaluation which consists of formative evaluation and summative evaluation. Formative evaluation: obtained from expert/expert and practitioner judgment. Summative evaluation is obtained from the final assessment value of students.

The data in this study were obtained through interviews, observation, and filling out questionnaires then the data were analyzed quantitatively. The analysis was conducted in the form of a validity test using the Product Moment formula, and the reliability test using the Alpha Cronbach formula. The next stage is an inferential statistical analysis to test the feasibility and effectiveness of the HBL model. To test the feasibility through expert validation, a validity test was conducted with a Likert scale. The Likert scale is a self-report technique for measuring attitudes where subjects are asked to indicate their level of agreement or disagreement with each statement. (Idrus Alwi, 2013: 106). This attitude is represented by the scores in each statement. The score categories on the Likert scale are as follows:

TABLE 1. Likert Scale Score

\begin{tabular}{|c|c|c|}
\hline No & Score & Description \\
\hline 1. & 5 & Very good \\
\hline 2. & 4 & Good \\
\hline 3. & 3 & Enough \\
\hline 4. & 2 & Less \\
\hline 5. & 1 & Very lacking \\
\hline
\end{tabular}

Obtaining data from the results of the validator's assessment is analyzed by the formula below:

$$
=\frac{\text { percentage score }}{\text { total assessment score }} \times 100 \%
$$

The percentage score obtained is then used in the study to determine the feasibility of the product developed using the following interpretation:

TABLE 2. Criteria for Achievement Level of Validation

As for analyzing the effectiveness of the HBL model, using the t-test. The t-test is carried out by

\begin{tabular}{|l|l|l|l|}
\hline No & Achievement Level & Qualification & Description \\
\hline 1. & $76 \%-100 \%$ & Very worthy & Used without revision \\
\hline 2. & $51 \%-75 \%$ & Well worth it & Can be used but needs minor revisions \\
\hline 3. & $26 \%-50 \%$ & Not feasible & $\begin{array}{l}\text { It is recommended not to use it because it needs a } \\
\text { major revision }\end{array}$ \\
\hline 4. & $\leq 25 \%$ & Very unworthy & Can not be used \\
\hline
\end{tabular}

comparing the t-count value with the t-

TABLE value. The results of the $t$ count above were compared with the $\mathrm{t}$ TABLE with a significance level of $5 \%(\propto=0.05)$ to determine whether there was a difference between before and after using the HBL model. If the significance level $<0.05$; it is

\section{RESULT AND DISCUSSION}

The research and development results are presented with three main points, namely (A) data presentation and data analysis, (B) discussion of development products; $(\mathrm{C})$ testing the effectiveness of the HBL model through science learning achievement, as follows:

\section{A. Data Presentation and Data Analysis}

In this sub-chapter, 6 things will be described, namely: instructional design expert testing, material expert testing, user trials, small group trials, and field trials. The six things will be presented consecutively according to the results obtained from each of the trial stages.

1. Instructional Design Expert Test

The instructional design expert in the development of the HBL learning model is someone stated that there is a significant difference in learning achievement. Meanwhile, if the results of the significance level> 0.05; it is stated that there is no significant difference in learning achievement. The results of this significance determine whether the HBL model is effective or not.

who has competence in the field of instructional design, namely Dr. R. Muktiono Waspodo a lecturer in Instructional Design at the Master of Educational Technology at UIKA Bogor as well as the Directorate General of Paud, Dikdas, and Dikmen; Directorate of PMPK, Ministry of Education and Culture. The instrument used for this instructional design expert trial was a questionnaire. The method used to collect data is a questionnaire method. After being converted to a Likert scale TABLE, the percentage level of achievement is $84 \%$ with very decent qualifications. At this stage, the expert stated that the HBL model was feasible without revision to be applied in the learning process in the pandemic era, but he suggested that it be equipped with a learning process monitoring instrument as well as a clear recapitulation of student feedback data that could be stated in the lesson plan. 


\section{Material Expert Test}

The material expert in the development of the HBL learning model is someone who has competence in the field of Natural Sciences, namely Mr. Galih Restu Fardian Suwandi, S.Si, M.Si, a lecturer at the Faculty of Mathematics and Natural Sciences, Bandung Institute of Technology (ITB). The instrument used for this instructional design expert trial was a questionnaire. The method used to collect data is a questionnaire method. After being converted to a Likert scale TABLE, the percentage level of achievement is $94 \%$ with very decent qualifications. At this stage, the expert stated that the HBL model was very suiTABLE for use with minor revisions and could be applied in the learning process in the pandemic era. He suggested including an assessment rubric (assessment) on the Project design document and the inclusion of time allocation (in minutes) for each activity.

\section{User Trial}

As a development product that has been revised based on the assessment of instructional design experts and material experts, then a user trial is carried out as the subject is the teacher and the parents of students as facilitators in the learning process. The instrument used for user testing was a questionnaire. The method used to collect data is a questionnaire method. After being converted to a Likert scale TABLE, the percentage level of achievement is $67 \%$ for the test results from teachers with proper qualifications and $79.1 \%$ for the test results from the parents of students with very decent qualifications.

\section{Small-Group Trials}

After going through the individual trial phase, then a small group trial was carried out involving ten students as respondents by filling out a questionnaire. The assessment carried out by ten students was still focused on the material aspects and the overall model. After being converted to a Likert scale TABLE, the percentage level of achievement is $93 \%$ with a very decent qualification/predicate.

5 .

Field Trial

The final stage was field trials which were aimed at 3rd-grade students of SD Sekolah Alam Indonesia Cibinong with science subjects as research objects.

B. Discussion of Product Development

The HBL-SAI program is not transferring lessons from school to home. HBL-SAI actually makes the house a learning medium through 2 main elements, namely the Home Program and Home PjBL. The hope is that HBL-SAI can be a solution to distance learning problems during a pandemic where it can become HBL SAI in the middle of PJJ or a form of home refreshing, for both children and parents, where children as learning subjects will "learn" without feeling "learning". Here the authors describe the elements of HBL SAI: (1) Home Program. Home Program is an activity to install students with good habits in the form of daily activities, from waking up to going back to sleep. The teacher will guide the students' program at home with their parents. This program will elaborate on home and school in forming a learning mindset; because learning can be anywhere, anytime, and with anyone. All activities carried out are essentially a learning scenario. Even sleep can be a learning activity if educators can design learning.(2) Home PjBL. The Home Project Based Learning (Home $\mathrm{PjBL}$ ) is a complement to the Home Program. With the formation of both, SAI hopes that learning can run smoothly and students' competencies (both cognitive, affective, and psychomotor) can be fulfilled. Home PjBL is a PPA application at home. Through Home PjBL, Sekolah Alam Indonesia strives to make the school a miniature environmentally friendly civilization and an oasis, which is not only for teachers, students, and parents but also for the natural surroundings. Home PjBL was closed by a celebration. The celebration is done virtually. This theme celebration is carried out through the zoom application where students follow the celebration in a virtual zoom while the teacher guides the celebration from the school. Each student makes a video containing a presentation on the characteristics of tomato or ginger plants, including how to plant and care for them. The videos are collected for the classroom teacher, then the class teacher edits and assembles them into a single unit. The video was played via zoom during the celebration. Each student listens to the video that is played then does a question and answer session guided by the teacher. (3) Play Date. Playdate is a moment to release students' homesickness from a school atmosphere. For SAI students, school is not just a place to learn. There is a bond between students and the school atmosphere. Playdate is designed to be dynamic and fun while still implementing the prevailing health protocols. Playdate activities can be in the form of light exercise, caring for livestock, gardening, exchanging seeds or sowing seeds, reading books in the library, or even just playing at school. Playdate activities are often used by students to discuss and deepen the material face-to-face with the teacher. The teacher also uses play dates to catch up on the understanding of students who are lagging and learning difficulties online, as well as to conduct evaluations and assessments of these students. (4) Class Bubble. Class Bubble is a learning model by grouping students based on house distance, interests, or emotional attachment in one study group. Class Bubble can be guided by representatives of 
competent parents or class teachers or experts (experts in certain fields depending on the learning material) as the facilitators. Class Bubble implementation is an alternative strategy for students with learning difficulties online or a solution for parents who cannot accompany their children to study at home. Bubble classes can be done at home or done at school. (5) Teacher Visit. Teacher visit is a visit of educators (teachers/facilitators) to the homes of students as a form of friendship to light and care for the torch of 'the true learner'; because education is not just transferring knowledge and knowledge. But it is more than that. Education is to strengthen morality that is built from exemplary. Implementation of teacher visits by the needs of students and agreement with parents of students while still implementing health protocols. Teacher visits, besides being filled with direct learning with the teacher, are also filled with brainstorming between students and teachers, questions and answers and discussions regarding the implementation of PJJ, questions and answers related to what students feel, difficulties faced, and the desires of students regarding the learning process also the implementation of assessment and evaluation within a certain period. (6).Virtual Discussion. The essence of studying at the Indonesian Nature School is to gather experiences for a better life. So that the learning process is carried out with a student center and active learning approach, where students are the learning subjects. So to complement the Home Based Learning activities, virtual discussions were held to structure experiences and construct them into new knowledge and understanding, by optimizing various existing online tools and LMS. SD 3 Klaperboom uses Google Class Room as LMS, Google Meet and Zoom as online discussion media. Virtual discussions are held every day as an activity for students to learn. The virtual discussion was opened with a prayer together led by one of the students, followed by the storytelling by the teacher. Stories can come from the Koran, hadiths, or other inspirational stories that bring benefits to life. After telling the story, the activity continued with the delivery of material by the class teacher, followed by a discussion. Before closing, a daily evaluation was carried out regarding the learning material, the implementation of the home program, a brief question and answer regarding the material and questions and answers related to the students' feelings towards learning on that day. Then the activity was closed with a prayer led by the students again. (7) Parents Support. Parents Support or Parenting Support is a means to equalize perceptions and improve parental skills in assisting the HBL program because for SAI the same perception between home (parents) and school is one of the keys to the successful implementation of Home-Based Learning. Parenting Support is carried out in stages, starting from general matters through parenting grand, to practical technical matters through intensive discussions between parents and class teachers. Parenting Support can also be a means of personal consultation about the development achievements of students. The seriousness of parents in participating in parenting support activities will be very meaningful for students. To achieve the goals of education at SAI, the home (parents) and schools work together to provide the best support for the success of the HBL (Home Based Learning) program as an alternative to learning in the pandemic era.

C. Testing the Effectiveness of the HBL Model through Science Learning Achievement

Researchers conducted an assessment to see the learning achievement of grade 3 students at SD Sekolah Alam Indonesia Cibinong in science subjects by applying the HBL learning model. This value can also be used as an instrument to see the effectiveness of the HBL model by using the paired two-sample t-test. Before the t-test is carried out, first the normality test is carried out and by calculating the normality test, the data is declared to be normally distributed. The results of the normality test are as follows:

TABLE 3: Normality Test Results

One-Sample Kolmogorov-Smirnov Test

\begin{tabular}{|llr|r|}
\hline & & \multicolumn{1}{c|}{ Hasil Belajar } \\
\hline N & & 41 \\
& Mean & 77,95 \\
& Std. Deviation & 4,950 \\
Most Extreme Differences & Absolute &, 148 \\
& Positive &, 144 \\
Kolmogorov-Smirnov Z & Negative &,- 148 \\
Asymp. Sig. (2-tailed) & & &, 950 \\
& Sig. &, 328 \\
Monte Carlo Sig. (2-tailed) & & &, $288^{c}$ \\
& 99\% Confidence Interval & Lower Bound &, 276 \\
& & Upper Bound &, 299 \\
\hline
\end{tabular}


After the normality test is carried out, then the t-test is carried out as follows:

TABLE 4: Paired Sample Statistics Results

Paired Samples Statistics

\begin{tabular}{|rr|r|r|r|r|}
\hline & & \multicolumn{1}{|c|}{ Mean } & N & Std. Deviation & Std. Error Mean \\
\hline \multirow{2}{*}{ Pair 1 } & Pre test & 75,24 & 21 & 4,288 &, 936 \\
& Pos test & 81,05 & 21 & 4,006 &, 874 \\
\hline
\end{tabular}

The data above shows the summary statistics of the two samples where descriptively there are differences in the average learning outcomes of the pre-test and post-test. The pre-test value means the value before applying the HBL, an average value of 75.24 is obtained, while the value of 2 is the value after using the HBL Model, an average value of 81.05 is obtained so that it can be stated that there has been a change in student learning achievement in science subjects. Thus, it can be stated that the HBL model is effectively applied during the pandemic, seen from the difference in the mean of -5.81 from the pre-test and post-test values. The difference in value indicates an increase of 5.81 from the average before implementing HBL.

TABLE 5: Paired Sample Test Results

Paired Samples Test

\begin{tabular}{|c|c|c|c|c|c|c|c|c|c|}
\hline & & & Paire & Differe & ces & & & & \\
\hline & & Mean & $\begin{array}{c}\text { Std. } \\
\text { Deviation }\end{array}$ & $\begin{array}{l}\text { Std. } \\
\text { Error }\end{array}$ & $\begin{array}{r}95 \% \mathrm{C} \\
\text { Interv } \\
\text { Diffe }\end{array}$ & $\begin{array}{l}\text { fidence } \\
\text { of the } \\
\text { nce }\end{array}$ & $t$ & $d f$ & $\begin{array}{l}\text { Sig. (2- } \\
\text { tailed) }\end{array}$ \\
\hline & & & & & Lower & Upper & & & \\
\hline Pair 1 & $\begin{array}{l}\text { Pre test - } \\
\text { Pos test }\end{array}$ & $-5,810$ & 4,771 & 1,041 & $-7,981$ & $-3,638$ & $-5,580$ & 20 & ,000 \\
\hline
\end{tabular}

The TABLE above from the test results using SPSS with a degree of confidence of $95 \%$, it can be seen in the TABLE that the significance (2-tailed) is $0.000<0.05$, it is stated that there is a significant difference in learning achievement. So it can be concluded that the use of the HBL model is effective in improving the learning achievement of grade $3 \mathrm{SD}$ Sekolah Alam Indonesia Cibinong in science subjects.

\section{CONCLUSION}

Based on the development process and the results of testing the HBL Model for grade $3 \mathrm{SD}$ Sekolah Alam Indonesia Cibinong, it can be concluded as follows: (1) The HBL model as a form of adaptation for $\mathrm{PjBL}$ during the pandemic is implemented with 7 elements, namely: home program, home PjBL, play date, class bubble, virtual discussion, teacher visit, and parents support. The selection of elements to be used in the learning process is tailored to the needs of students. This HBL model was developed using the ADDIE development model, (2) HBL is declared very feasible to be applied as an alternative learning model during the pandemic with a percentage of assessment: instructional design experts $84 \%$, material experts $94 \%$, by teachers with a percentage of $67 \%$, people $79 \%$ of students' parents, and students with a percentage of $93 \%$. (3) There is a change in science learning achievement achieved by students after implementing HBL. This is evidenced by the difference in the mean value at the pre-test at 75.24 and the post-test at 81.05. Based on the data analysis carried out, the HBL Model is effectively applied because it can improve student achievement during the Covid-19 pandemic.

\section{REFERENCES}

[1] M, Sardiman.(2001). Interaksi dan Motivasi Belajar Mengajar. Jakarta: Raja Grafindo

[2] Anderson, L.W. \& Krathwohl, D.R. (Eds). (2015). Kerangka Landasan Untuk Pembelajaran, Pengajaran, Dan Asesmen: Revisi Taksonomi Pendidikan Bloom (Terjemahan Agung Prihantoro). Yogyakarta: Pustaka Pelajar.

[3] Alwi, Idrus. (2013). Metodologi Penelitian Pendidikan suatu Pendekatan Proposal. Jakarta: Saraz Publishing. 
[4] Jufri, DR.H.A. Wahab, M.Sc. (2013). Belajar dan Pembelajaran Sains. Bandung: Pustaka Reka Cipta.

[5] Sagala, Syaiful. (2011). Konsep dan Makna Pembelajaran. Bandung: Alfabeta

[6] Suryabrata, Sumadi drs B.A., M.A., Ed.s., Ph.d. (2010). Psikologi Pendidikan. JakartaRajawali Perss.

[7] Sutirman. (2013). Media dan ModelModel Pembelajaran Inovatif. Yogyakarta: Sutirman. 